\title{
TINGKAT PEMENUHAN INFORMASI MITIGASI PENANGGULANGAN BENCANA MELALUI ILM PADA LPP TVRI BALI
}

\author{
I Nengah Muliarta \\ Warmadewa Research Centre (WaRC). \\ Jl. Terompong 24 Tanjung Bungkak Denpasar Bali, Indonesia \\ e-mail: nengahmuliarta@gmail.com
}

\begin{abstract}
ABSTRAK
TVRI merupakan salah satu lembaga penyiaran publik yang dalam proses penyiarannya menggunakan frekuensi publik dan operasionalnya menggunakan dana publik melalui alokasi anggaran dari pemerintah. Sebagai lembaga penyiaran publik, TVRI memiliki kewajiban untuk memberikan pendidikan dan informasi bagi publik. Kewajiban tersebut, salah satunya dapat dilakukan melalui siaran yang dilakukan dalam format siaran iklan layanan masyarakat (ILM). Penelitian ini bertujuan untuk mengetahui tingkat pemenuhan penyebaran mitigasi bencana melalui ILM yang dilakukan oleh TVRI Bali, sehingga kedepan dapat dibuat perencanaan guna memaksimalkan penyebaran mitigasi bencana melalui ILM. Penelitian dilakukan dengan mengambil data susunan acara TVRI Bali selama bulan Oktober hingga Desember 2018. Hasil penelitian menunjukkan bahwa TVRI Bali belum melakukan pemenuhan informasi terkait mitigasi bencana, terbukti belum adanya iklan layanan masyarakat yang diproduksi dan disiarkan yang terkait dengan mitigasi bencana. Secara umum juga TVRI Bali belum memenuhi batas minimum persentase pemenuhan penyiaran ILM sesuai dengan Undang-Undang Penyiaran, Pedoman Perilaku penyiaran (P3) dan Standar Program Siaran (SPS).
\end{abstract}

Kata Kunci: Mitigasi, Penanggulangan Bencana, ILM, Lembaga Penyiaran, TVRI

\begin{abstract}
TVRI is a public broadcasting institution that in its broadcasting process uses public frequencies and its operations use public funds through budget allocations from the government. As a public broadcasting institution, TVRI has an obligation to provide education and information to the public. This obligation, one of which can be done through broadcasts that are carried out in the form of public service advertisements (PSA). This study aims to determine the level of fulfillment of the spread of disaster mitigation through PSA carried out by TVRI Bali, so that future plans can be made to maximize the spread of disaster mitigation through PSA. The research was conducted by taking data from the TVRI Bali program during October to December 2018. The results showed that TVRI Bali had not fulfilled information related to disaster mitigation, as evidenced by the absence of public service advertisements produced and broadcast related to disaster mitigation. In general, TVRI Bali has not met the minimum percentage of PSA broadcasting compliance in accordance with the Broadcasting Law, Broadcasting Behavior Guidelines (BBG) and Broadcast Program Standards (BPS).
\end{abstract}

Keywords: Mitigation, Disaster Management, PSA, Broadcasting Institutions, TVRI

\section{PENDAHULUAN}

Bali menjadi salah satu daerah yang rawan bencana, buktinya pernah terjadi gempa besar tahun 1815 yang dikenal dengan gejer Bali atau Bali bergetar (Ardiyasa dan Suadnyana, 2017). Termasuk daerah yang rawan terhadap letusan gunung berapi yaitu Gunung Agung yang berada di wilayah Kabupaten Karangasem (Inan et al., 2018). Bali 
juga menjadi wilayah yang rawan terhadap bencana akibat kejahatan terorisme. Buktinya yaitu kasus Bom Bali 2002 dan Bom Bali 2005 (Ambarita, 2018). Tragedi serangan terorisme di Bali mengungkapkan sejumlah tantangan dan pelajaran bagi pemangku kepentingan dalam mitigasi bencana di Bali (Gurtner, 2016).

Konsep mitigasi bencana menjadi bagian awal dalam sebuah manajemen bencana, karena memiliki keterkaitan dengan proses kebijakan publik. Dengan dimasukkannya mitigasi bencana dalam agenda kebijakan maka proses perumusan, implementasi dan evaluasi kebijakan dapat dilakukan untuk menentukan arah kebijakan penanggulangan yang bersifat pra bencana pada pembangunan daerah (Faturahman, 2018). Mitigasi bencana adalah kegiatan awal sebelum terjadinya bencana sebagai upaya untuk mengurangi resiko atau kerugian akibat bencana (Dennis et al., 2016). Selama ini masih terdapat kecenderungan keengganan untuk melakukan langkah-langkah pengurangan bencana atau mitigasi. Salah satu alasan keengganan melakukan langkah-langkah antisipasi bencana yaitu masih adanya anggapan bahwa pemerintah akan melakukan langkah pemberian bantuan dan rehabilitasi akibat dampak dari bencana (Kunreuther, 2006).

Peran komunikasi dalam bencana sangat menentukan keberhasilan yang diinginkan oleh pemerintah dalam memberikan informasi bagi keamanan masyarakat dan mengatasi permasalahan bencana yang terjadi (Asteria, 2016). Selain informasi mengenai yang memadai tentang potensi bencana di suatu daerah, kegiatan pelatihan dan termasuk internalisasi kebiasaan masyarakat dalam menghadapi situasi bencana semestinya juga harus dilakukan terus menerus secara berkesinambungan. Namun mesti diingat, bahwa informasi yang berlimpah tidak cukup untuk menyadarkan masyarakat atas kemungkinan bencana yang sewaktu-waktu mengancam (Rudianto, 2015). Perlu juga sistem komunikasi yang cukup cepat dan akurat saat bencana terjadi, guna meminimalkan resiko bencana (Suhardjo, 2011). Strategi penyampaian dan penyajian informasi juga harus dilakukan secara tepat. Kekeliruan dalam menyampaikan sebuah informasi, dapat menimbulkan salah pengertian yang justru memperburuk situasi. Manajemen komunikasi krisis yang baik akan membuat fungsi koordinasi dan pengambilan keputusan pemerintah berjalan stabil (Rudianto. 2015). Dimana optimalisasi komunikasi bencana secara terpadu penting dalam manajemen bencana yang dapat dilakukan dengan pelibatan media massa (Asteria, 2016). Dalam penanggulangan bencana, komunikasi bisa hadir sebagai fungsi sosialisasi dan penyebarluasan informasi, fungsi manajemen dan koordinasi dan fungsi konseling dan rehabilitasi (Rudianto. 2015). Peluang untuk mengurangi ketidakpastian pada situasi bencana dapat dilakukan dengan ketersediaan informasi yang memadai terutama dalam peritiwa bencana ketika banyak sumberdaya yang dibutuhkan dalam waktu yang bersamaan dan dalam periode yang tidak pasti (Wardyaningrum, 2018). Masyarakat yang terkena dampak langsung bila bencana itu datang, memiliki harapan tinggi agar informasi apapun segera dapat diketahui. Artinya secara tegas mereka ingin mengatakan kepada pemerintah daerahnya agar media untuk informasi kebencanaan itu dibuat atraktif dan mudah dimengerti (Priyowidodo dan Luik, 2013).

Media massa menjadi media yang setiap saat mendidik masyarakat supaya cerdas, terbuka pikirannya, dan menjadi masyarakat yang maju (Neonisa, 2011). Apalagi teknologi media telah berkembang secara merata dan dialami semua lini masyarakat. Bahkan telah memasuki batas-batas strata sosial, dimana masyarakat kota ataupun desa memiliki akses yang hampir sama dalam memperoleh informasi (Priyowidodo dan Luik, 2013). Lembaga 
penyiaran televisi menjadi salah satu media komunikasi yang bisa dimanfaatkan untuk menyebarluaskan dan mensosialisasikan isu terkait mitigasi bencana. Ketentuan pasal 4 ayat (1) Undang-Undang No. 32 tahun 2002 tentang Penyiaran menyebutkan bahwa "Penyiaran sebagai kegiatan komunikasi massa mempunyai fungsi sebagai media informasi, pendidikan, hiburan yang sehat, kontrol dan perekat sosial". Sebagai lembaga penyiaran publik sudah sepatutnya Televisi Republik Indonesia (TVRI) menjadi salah satu televisi yang memiliki kewajiban untuk melakukan penyebarluasan informasi kebencanaan. Dalam Peraturan Pemerintah (PP) No. 11 Tahun 2005 tentang Penyelenggaraan Penyiaran Lembaga Penyiaran Publik, khususnya pada Bab I, Pasal 1 ayat (2) disebutkan bahwa "Lembaga Penyiaran Publik adalah lembaga penyiaran yang berbentuk badan hukum yang didirikan oleh negara, bersifat independen, netral, tidak komersial, dan berfungsi memberikan layanan untuk kepentingan masyarakat".

Perkembangan pertelevisian di Indonesia diawali saat Indonesia menjadi tuan rumah Asian Games IV yang digelar di Jakarta pada tahun 1962. Pada era tersebut, TVRI muncul dan menjadi pelopor lahirnya industri pertelevisian di Indonesia. Saat itu TVRI menjadi alat komunikasi antara pemerintah dengan rakyatnya, disamping TVRI menjadi media hiburan bagi kaum elite politik dan elit pemerintahan (Mustika, 2012). TVRI (Televisi Republik Indonesia) merupakan stasiun televisi pertama di Indonesia. TVRI didirikan tanggal 24 Agustus 1962. TVRI dahulunya merupakan media perpanjangan tangan pemerintah dengan tugas menyampaikan kebijakan-kebijakan pemerintahan kala itu kepada masyarakat (Ayu et al., 2016). Status kelembagaan TVRI, yang kemudian berubah menjadi Lembaga Penyiaran Publik semakin menegaskan bahwa lembaga pernyiaran ini diperuntukkan melayani kepentingan masyarakat dengan anggaran operasional yang dibiayai oleh negara. Kreativitas dalam pengelolaan program acara menjadi factor penentu dalam memperoleh dukungan pihak sponsor acara. Berbagai strategi bisa dilakukan untuk mengoptimalkan pemasukan lembaga dengan membuka lebih banyak peluang yang dapat dimanfaatkan oleh pihak sponsor sebagai upaya pencitraan di tengah masyarakat (Keizer, 2010). Sejak perubahan statusnya menjadi stasiun penyiaran publik, LPP TVRI baik di pusat maupun daerah masih terus berbenah diri untuk menjadi sebuah stasiun penyiaran publik yang dapat mengakomodir dan memberikan pelayanan informasi kepada publik sebagai audiensnya (Wulandari, 2016). Dimana sebagian besar anggaran operasional TVRI merupakan anggaran APBN yang disubsidi pemerintah (Keizer, 2010). Sebagaimana diketahui, status TVRI baik itu stasiun penyiaran pusat maupun daerah sebelum era penyiaran publik, selama berpuluh-puluh tahun bisa dipastikan lebih mengarah pada model penyiaran pemerintah (Wulandari, 2016).

Televisi sebagai industri bisnis menunjukkan kecenderungan orientasi komersial dan hanya memberikan sedikit perhatian pada upaya pembentukan nilai-nilai moral yang berkepribadian dan beridentitas kebangsaan serta peningkatan kualitas intelektual (Mustika, 2012). Hal ini membuat TVRI tidak memiliki alternatif pilihan untuk bertahan hidup selain dengan mengakomodir beberapa kepentingan tertentu, baik dari pemerintah ataupun dari pihak pemberi sponsor. Meskipun hal tersebut bertentangan dengan prinsip TV publik yang independen, netral dan tidak komersial (Wulandari, 2016). Sedangkan pada industri televisi swasta, iklan menjadi nafas kehidupan dan tumpuan keberlangsungan media televisi. Dinamika pasar telah membuat TV berorientasi pada etika konsumsi dengan program acara-acara yang sepenuhnya untuk memenuhi selera khalayak demi mengundang 
pengiklan (Mustika, 2012). Berbeda dengan Jepang yang memiliki penyiaran komersial yang dibiayai oleh pendapatan iklan dan lembaga penyiaran publik, Nippon Hoso Kyokai (NHK) atau lembaga penyiaran Jepang yang pembiayaan melalui iuran sukarela pemirsanya (Nakamura dan Bourdeau, 2006).

Penyebarluasan informasi melalui media tidak saja dapat dilakukan dalam bentuk berita, tetapi juga dapat dalam bentuk iklan. Menurut Keizer (2010), Iklan biasanya ditujukan untuk mendorong konsumen untuk membeli suatu produk. Namun demikian, hasil riset terhadap perilaku konsumen bersedia membeli salah satu diantaranya adalah reputasi dan citra produsen. Hal inilah yang mendorong beberapa perusahaan untuk melakukan kegiatan periklanan dalam bentuk iklan korporat melalui berbagai media yang ada. Secara teori iklan terbagi menjadi dua yaitu iklan komersial dan iklan atau pesan layanan masyarakat (ILM). ILM mendukung kampanye publik yang beragam dan memiliki kehadiran yang berpengaruh di masyarakat. Dilihat dari sudut pandang teknis, iklan ini menunjukkan fleksibilitas dan kemampuan beradaptasi dari metode periklanan, menunjukkan bahwa mereka dapat digunakan untuk mempromosikan perilaku sosial yang positif (Barr, 2012). Istilah ILM di Indonesia pada dasarnya mengadopsi konsep Public Service Advertisement yang kemudian dikenal dengan istilah Public Service Announcement atau PSA, dimana istilah PSA diperkenalkan pertama kali di Amerika Serikat. UndangUndang No. 32 tahun 2002 mengenai Penyiaran, khususnya Pasal 1 ayat (7) disebutkan bahwa "Siaran iklan layanan masyarakat adalah siaran iklan nonkomersial yang disiarkan melalui penyiaran radio atau televisi dengan tujuan memperkenalkan, memasyarakatkan dan atau mempromosikan gagasan, cita-cita, anjuran dan atau pesan-pesan lainnya kepada masyarakat untuk mempengaruhi khalayak agar berbuat dan atau bertingkah laku sesuai dengan pesan iklan tersebut".

ILM merupakan bagian dari kampanye social marketing yang bertujuan menjual gagasan atau ide untuk kepentingan atau pelayanan masyarakat (Hastuti, 2013 ; Mustika dan Zakaria. 2014). Iklan atau pesan Layanan Masyarakat (ILM) juga menjadi salah satu bentuk strategi promosi yang sering digunakan dalam aktivitas pemasaran sosial. Sama halnya dengan iklan komersial, penyajian ILM dituntut mampu efektif sehingga pesan persuasifnya dapat merubah perilaku masyarakat yang menjadi target agar sesuai dengan keinginan pemasang iklan (Nisa, 2015). Penggunaan iklan layanan masyarakat diharapkan mampu untuk menyampaikan pesan kepada public yang lebih luas dibandingkan dengan format penyajian media televisi lainnya seperti running text ataupun dialog interaktif (Neonisa, 2011). Tujuan utama ILM adalah mendorong perhatian dan kemauan seseorang untuk merubah perilakunya menjadi lebih baik atau seperti yang diharapkan pemasar sosial. Untuk itu, hal terpenting yang harus dilakukan pemasar sosial adalah menciptakan strategi yang kreatif untuk pesan dan penempatan medianya secara tepat baik untuk targetnya dan makna pesan yang disampaikan. Sebuah tayangan iklan dapat dikatakan sukses jika suatu produk atau pesan yang disampaikan menjadi akrab di telingan dan mata khalayak sasaran. Namun menjadi berat untuk mencapai tujuan iklan tersebut, mengingat untuk sebuah ILM yang frekuensi penayangannya tidak serutin iklan komersial dan kemasan iklan yang kurang menarik (Mustika dan Zakaria, 2014). Perlu sebuah kreativitas dalam pembuatan ILM agar ILM yang dibuat mampu menarik perhatian pemirsa atau pendengar. iklan juga semestinya mampu memunculkan minat, sehingga mampu memberi inspirasi dan mampu merubah perilaku agar sesuai dengan anjuran dalam iklan. Sebuah iklan yang kreatif dapat 
membentuk sebuah kebutuhan pada target adopternya. Iklan juga mestinya bisa mendorong target adopter untuk melakukan perubahan perilaku agar sesuai dengan yang diinginkan pemasar sosial (Nisa, 2015).

Tayangan ILM di televisi dapat menjadi dari bagian strategi promosi jangka panjang dan juga upaya memperluas jangkauan penyebaran informasi. Dimana setiap ILM memiliki durasi waktu yang berbeda, biasanya terdapat yang menggunakan durasi 30 dan 60 detik da nada juga yang menggunakan 15 dan 20 detik per-spot (Cooper et al., 2015). Penyiaran ILM oleh radio lokal atau stasiun televisi berguna bagi lembaga layanan publik sebagai mekanisme untuk menjangkau klien potensial selama periode waktu tertentu (McAbee dan Cafferty, 1982).Terlepas dari biaya yang relatif lebih mahal dalam menggunakan iklan layanan masyarakat dalam media televisi dibandingkan media lainnya, iklan layanan masyarakat dalam media televisi memiliki keunggulan, seperti kesan relaisitik, repitisi/pengulangan dan dapat mencakup masyarakat luas (Neonisa, 2011).

Permasalahannya hingga saat ini masih sangat jarang terdapat penelitian mengenai analisis terhadap pemenuhan penyebaran informasi mitigasi bencana oleh lembaga penyiaran dalam bentuk iklan layanan masyarakat. Selain itu belum pernah ada dilakukan evaluasi terhadap ketaatan lembaga penyiaran terhadap kewajiban menayangkan iklan layanan masyarakat, khususnya yang berkaitan dengan upaya sosialisasi dan edukasi mitigasi bencana. Atas dasar alasan tersebut penelitian ini menjadi penting dilaksanakan untuk nantinya dapat digunakan dalam penyusunan strategi penyebarluasan informasi dan sosialisasi mitigasi bencana melalui lembaga penyiaran.

\section{METODOLOGI PENELITIAN}

Penelitian ini menggunakan pendekatan studi kasus, suatu pendekatan yang menelaah kepada satu kasus yang dilakukan secara mendalam. Pendekatan studi kasus dilakukan untuk dapat mengungkapkan fenomena sosial, dan dengan studi kasus menguntungkan peneliti karena dapat mengumpulkan data yang lengkap dan mendalam. Penelitian ini terbatas pada kajian terhadap pemenuhan TVRI Bali sebagai lembaga publik dalam memenuhi kewajiban dan peran sertanya dalam penyebarluasan informasi mitigasi kebencanaan di Bali.

Penelitian dilakukan dengan mengambil data susunan acara TVRI Bali selama bulan Oktober hingga Desember 2018, kemudian pada masing-masing bulan diambil sampling data dari tanggal 1-7. Data yang didapatkan kemudian dihitung durasi penayangan iklan atau pesan layanan masyarakat. Durasi penayangan iklan atau pesan layanan masyarakat kemudian dipilah kembali untuk mendapatkan durasi penayangan iklan atau pesan layanan masyarakat yang khusus terkait mitigasi penanggulangan bencana. Data yang didapatkan kemudian di analisis secara deskritif dan dibandingkan dengan aturan yang ada, baik Undang-Undang Penyiaran (KPI, 2008), Peraturan Komisi Penyiaran Indonesia No. 01/P/KPI/03/2012 mengenai Pedoman Perilaku Penyiaran (P3) dan Peraturan Komisi Penyiaran Indonesia No. 02/P/KPI/03/2012 mengenai Standar Program Siaran (SPS).

Dalam penelitian ini juga dilakukan wawancara terhadap narasumber yang merupakan pemegang kebijakan, seperti disajikan dalam Tabel 1. Wawancara ini bertujuan 
untuk menggali permasalahan dan hal-hal yang menjadi tantangan dalam upaya penyebarluasan informasi mitigasi bencana melalui lembaga penyiaran.

Tabel 1

Narasumber

\begin{tabular}{cll}
\hline No. & \multicolumn{1}{c}{ Nama narasumber } & \multicolumn{1}{c}{ Jabatan } \\
\hline 1. & Drs. Juremi Wijaya & Direktur Program TVRI Bali \\
2. & I Made Rentin & Kepala Pelaksanana Badan Penanggulangan \\
& & Bencana Daerah (BPBD) Bali \\
3. & I Gusti Ngurah Murthana, ST & Wakil Ketua Komisi Penyiaran Indonesia \\
& & (KPID) Bali \\
\hline
\end{tabular}

\section{HASIL DAN PEMBAHASAN}

Hasil penelitian menunjukkan bahwa TVRI Bali secara keseluruhan dalam satu hari bersiaran selama 20 jam. Namun siaran khusus lokal Bali hanya 4 jam dan sisanya merupakan siaran relai dari TVRI Jakarta (Gambar 1).

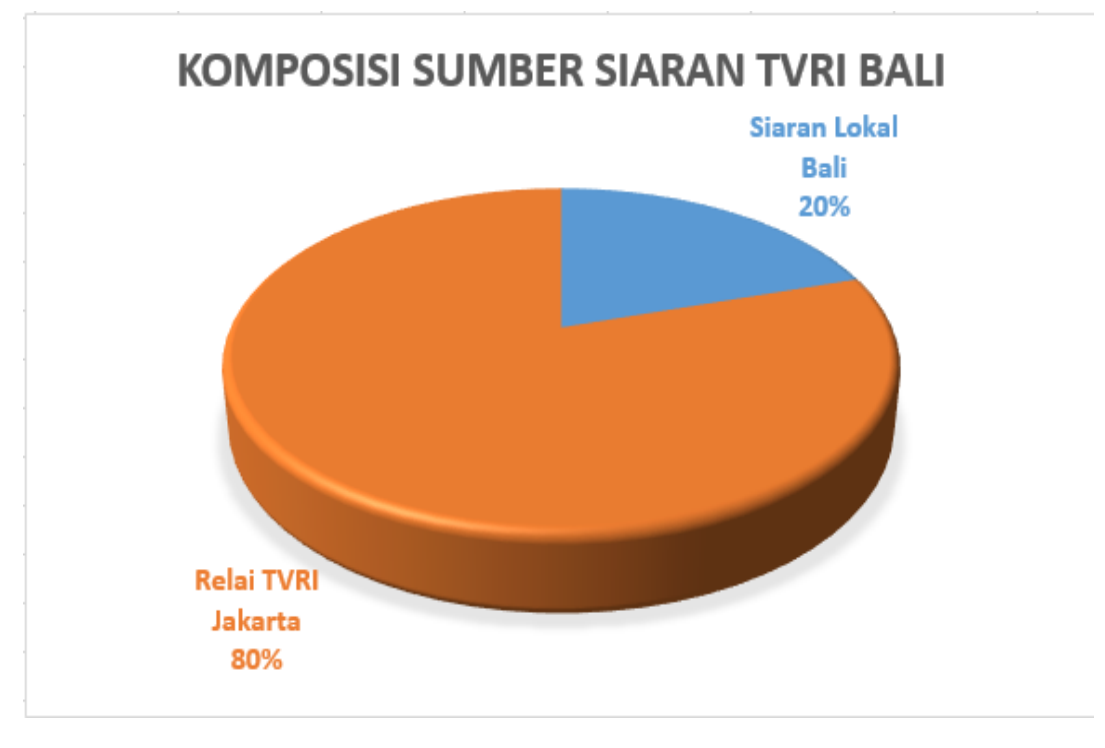

Gambar 1

Komposisi sumber siaran TVRI Bali

Siaran lokal dilakukan dari pukul 15.00-19.00 Wita, namun sejak bulan April 2019 siaran lokal diubah yaitu dari pukul 09.00-11.00 Wita dan 17.00-19.00 Wita. Tercatat dari 4 jam siaran khusus TVRI Bali tidak ada menayangkan iklan komersial. Berdasarkan pasal 46 ayat (8) Undang-Undang No. 32 tahun 2002 mengenai Penyiaran disebutkan bahwa waktu siaran iklan niaga untuk lembaga penyiaran publik paling banyak $15 \%$ dari seluruh waktu siaran. Dimana siaran niaga yang dimaksud terdiri dari siaran komersial dan siaran iklan layanan masyarakat. Menurut Kasi Pengembangan Usaha, TVRI Bali, Sunar Wardoyo (wawancara 8 Mei 2019), tidak adanya iklan komersial karena secara umum iklan komersial penawarannya dibawa oleh agen dan rata-rata agen minta potongan harga untuk mencari keuntungan. Negosiasi harga tersebut tidak dapat dipenuhi oleh TVRI Bali karena harga yang diberikan sudah sesuai dengan Peraturan Pemerintah (PP) No. 33 Tahun 
2018 terkait pengaturan besaran harga penerimaan Negara bukan pajak (PNBP), sehingga harga tidak dapat diubah karena langsung masuk dalam sistem kas Negara.

Ditinjau dari durasi ILM yang disiarkan TVRI Bali rata-rata mencapai 600,48 detik untuk 4 jam (14.400 detik) waktu siaran lokal TVRI Bali (Gambar 2).

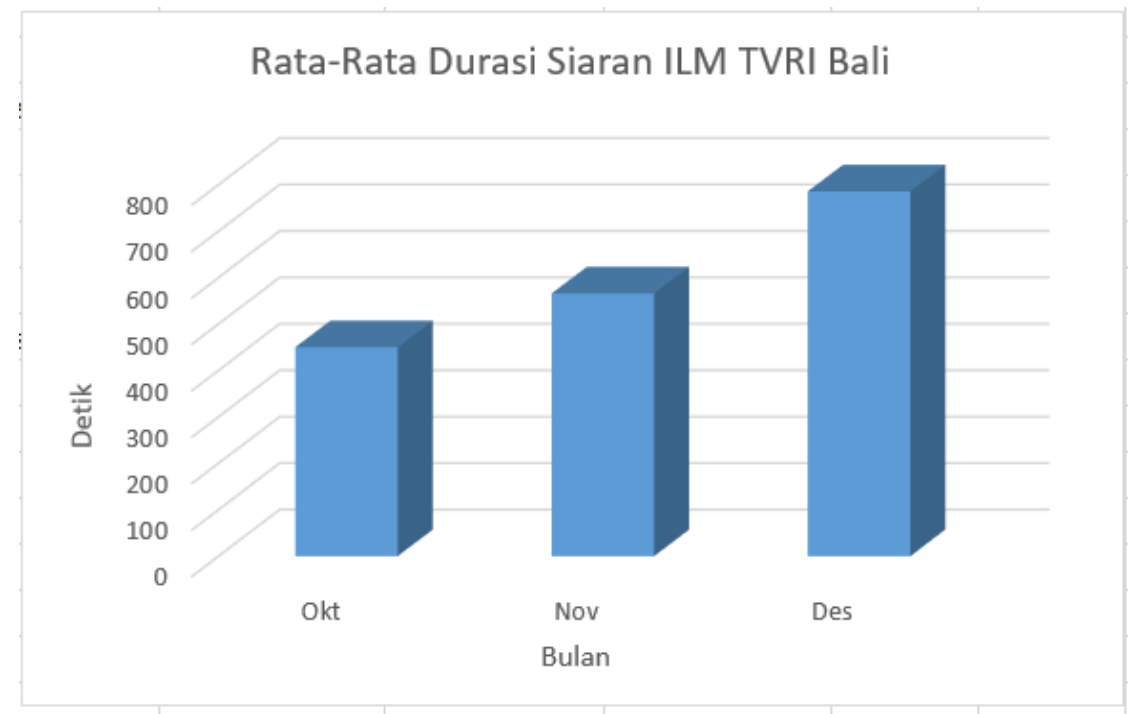

Gambar 2

Durasi siaran ILM TVRI Bali selama Oktober-Desember 2018

Apabila dipersentasekan maka rata-rata durasi ILM yang disiarkan TVRI sebesar 4,17\%. Merujuk kembali Pasal 46 ayat (8) Undang-Undang Penyiaran disebutkan waktu siaran iklan niaga untuk lembaga penyiaran publik paling banyak $15 \%$ dari seluruh waktu siaran, maka TVRI Bali memiliki durasi siaran iklan niaga mencapai 2.160 detik. Apabila kemudian merujuk pada Pasal 46 ayat (9) Undang-Undang Penyiaran disebutkan waktu siaran iklan atau pesan layanan masyarakat untuk lembaga penyiaran publik paling sedikit 30 persen dari siaran iklannya, maka TVRI Bali memiliki durasi penayangan ILM mencapai 648 detik. Apabila dipersentasekan, dalam 4 jam siaran TVRI Bali sesuai ketentuan dalam pasal 46 Undang-Undang penyiaran maka ILM seharusnya minimal 4,5\%. Jadi persentase penayangan ILM oleh TVRI Bali belum memenuhi ketentuan minimal yang disyaratkan. Hasil ini sejalan dengan pernyataan Komisioner KPI, Ubaidillah yang menyatakan bahwa penayangan ILM di di lembaga penyiaran secara umum masih sangat minim. Penyiaran ILM juga condong dilakukan pada waktu siaran dengan jumlah penonton yang sedikit atau tidak di waktu prime time (Beritabali, 2018).

Bila ditinjau dari rata-rata jumlah ILM yang ditayangkan oleh TVRI Bali dalam 4 jam siaran dalam satu hari berjumlah 10 ILM. Jika kembali pada perhitungan bahwa TVRI Bali memiliki durasi penayangan ILM mencapai 648 detik, maka dalam 4 jam siaran seharusnya TVRI Bali menyiarkan 11 ILM berdurasi 60 detik atau 22 ILM berdurasi 30 detik dengan catatan tidak ada ILM yang diputar ulang dalam satu hari. Selama ini TVRI Bali menayangkan ILM dengan durasi yang cukup beragam yaitu 30 detik, 60 detik, 80 detik dan 90 detik per-spot. Durasi ILM yang beragam di TVRI Bali ini sejalan dengan pandangan Cooper et al., (2015) yang menyatakan ILM memiliki durasi waktu yang 
berbeda, dimana ada yang menggunakan durasi 30 dan 60 detik dan ada juga yang menggunakan 15 dan 20 detik per-spot. TVRI Bali juga menayangkan ILM dengan durasi yang cukup panjang yaitu 80 detik dan 90 detik per-spot, durasi panjang ini dapat dikatakan diluar kewajaran dan dapat merugikan, karena selain dapat mengurangi jumlah keberagaman ILM yang ditayangkan, dapat pula berpengaruh terhadap harga ILM per-spot. Namun kebijakan durasi iklan 80 detik dan 90 detik per-spot menjadi wajar ketika harga spot dengan durasi panjang tersebut menjadi lebih tinggi. Berdasarkan PP Nomor 33 Tahun 2018 terkait pengaturan besaran harga Penerimaan Negara Bukan Pajak, harga ILM dengan durasi 30 detik sebesar Rp. 250.000, durasi 60 detik sebesar Rp. 350.000 dan 90 detik sebesar Rp.400.000.

Berdasarkan data terungkap bahwa dari ILM yang disiarkan TVRI Bali selama 4 jam siaran dalam satu hari sebanyak 68,83\% merupakan produksi sendiri yang ditayangkan secara cuma-cuma dan hanya 31,71 merupakan ILM produksi lembaga lain dan berbayar. Hal ini berarti TVRI Bali telah menjalankan amanat Pasal 44 ayat (4) Peraturan Komisi Penyiaran Indonesia No. 01/P/KPI/03/2012 mengenai Pedoman Perilaku Penyiaran (P3) yang menyebutkan bahwa lembaga penyiaran wajib menyediakan slot iklan secara cumacuma sekurang-kurangnya 50 persen dari seluruh siaran iklan layanan masyarakat per-hari untuk iklan layanan masyarakat yang berisi : keselamatan umum, kewaspadaan pada bencana alam, dan/atau kesehatan masyarakat, yang disampaikan oleh badan-badan publik. Namun dari 10 ILM yang rata-rata disiarkan TVRI Bali tidak ada satu pun ILM terkait mitigasi bencana dan yang ada hanya bentuk promo panggilan darurat. Promo panggilan darurat dengan durasi 30 detik dan rata-rata diputar berulang 2-3 kali dalam 4 jam siaran tersebut hanya berisikan ajakan menghubungi call center apabila sedang menghadapi kegawatdaruratan. Hasil ini memberikan gambaran bahwa selama ini penyebaran informasi mitigasi bencana melalui lembaga penyiaran publik belum dimanfaatkan dan TVRI Bali sebagai lembaga penyiaran yang seharusnya mengutamakan kepentingan publik juga belum mengambil peran. Buktinya belum ada ILM yang khusus disiarkan terkait upaya penyebaran informasi mitigasi bencana secara periodik dan berkelanjutan. Hal ini memberi petunjuk bahwa peluang untuk menyebarkan informasi mitigasi bencana melalui lembaga penyiaran sangat terbuka, peluang yang ada juga harus dimanfaatkan secara optimal agar jumlah korban dapat diminimalisir ketika terjadi bencana.

Kepala Pengembangan Program dan Pengembangan Usaha TVRI Denpasar, Drs. Juremi Wijaya (wawancara 8 Mei 2019) menyatakan produksi ILM dilakukan sesuai isu yang berkembang di daerah, seperti isu pemberlakuan pakaian adat Bali dan isu pengurangan timbulan sampah plastik. Namun isu terkait erupsi Gunung Agung tidak termanfaatkan untuk dibuatkan ILM, padahal masyarakat sangat membutuhkan informasi mitigasi bencana terkait Gunung Agung. Artinya kepekaan dalam menangkap isu untuk disajikan dan sesuai dengan konteks kebutuhan masyarakat nampaknya perlu lebih ditingkatkan. Kemudian juga perlu melihat skala prioritas dalam memilih isu untuk kemudian dibuatkan ILM, sebab hal ini juga dapat menjadi hal yang menarik bagi pemirsa di Bali untuk menjadikan TVRI Bali sebagai tontonan siaran wajib. Apabila terdapat keterbatasan materi ILM terkait mitigasi bencana, tentu TVRI Bali dapat berkoordinasi dengan BPBD Bali. Masing-masing dapat mengambil peran sesuai tugas dan fungsi masing-masing, misalnya BPDB Bali menyiapkan materi ILM dan TVRI Bali memproduksi serta menyiarkan ILM terkait mitigasi bencana. Dengan melakukan 
pembagian peran tersebut pada akhirnya BPBD Bali dapat memenuhi kewajibannya untuk memberikan informasi mitigasi bencana kepada masyarakat dan TVRI Bali dapat memenuhi kewajiban untuk menyediakan dan menyiarkan ILM sesuai ketentuan UndangUndang Penyiaran. Strategi lain yang dapat dilakukan yaitu, BPBD Bali menyiapkan dan memproduksi sendiri ILM terkait mitigasi bencana, kemudian ILM yang telah jadi tersebut disebarkan kepada seluruh lembaga penyiaran televisi di Bali untuk disiarkan. Langkah ini dapat dilakukan dengan catatan BPBD Bali memiliki alokasi dana untuk memproduksi dan memiliki SDM yang memiliki kemampuan untuk memproduksi ILM.

Dalam P3 juga telah memuat aturan tentang potongan harga terhadap iklan atau pesan layanan masyarakat. Pasal 44 ayat (5) P3 menyebutkan bahwa khusus untuk ILM yang berasal dari lembaga pemerintah atau institusi sosial, lembaga penyiaran wajib memberikan potongan harga sekurang-kurangnya 50 persen dari harga siaran iklan niaga. Ketentuan dalam pasal 44 ayat (4) dan (5) juga memuat ketentuan bahwa lembaga penyiaran memiliki kewajiban untuk memproduksi dan menyiaran ILM, tanpa harus menunggu adanya permintaan maupun pesanan dari lembaga atau badan publik. Implementasi Pasal 44 ayat (5) P3 ini berbenturan dengan PP Nomor 33 Tahun 2018 terkait pengaturan besaran harga Penerimaan Negara Bukan Pajak (PNBP). Namun dalam PP Nomor 33 Tahun 2018 juga terdapat kelonggaran, dimana disebutkan bahwa apabila lembaga tidak mempunyai anggaran sesuai ketentuan PNBP dapat mengajukan surat permohonan. Sedangkan dalam Peraturan Komisi Penyiaran Indonesia No. 02/P/KPI/03/2012 tentang Standar Program Siaran (SPS), pada pasal 60 ayat (3) dinyatakan program ILM wajib ditayangkan secara cuma-Cuma untuk iklan atau pesan layanan masyarakat yang menyangkut ; keselamatan umum, kewaspadaan pada bencana alam, kesehatan masyarakat, dan kepentingan umum lainnya yang disampaikan oleh badan-badan publik. Guna dapat menjalankan ketentuan tersebut maka TVRI Bali dapat membuat kesepakatan kerjasama dengan BPBD Bali untuk bersama-sama melakukan penyebarluasan informasi mitigasi bencana dalam bentuk ILM, termasuk juga dapat dalam bentuk pemberitaan dan dialog rutin.

Produksi dan penyiaran ILM yang dilakukan oleh TVRI Bali merupakan sebuah kesadaran akan tanggungjawab menggunakan frekuensi publik dan juga sebuah kesadaran akan tanggungjawab akan kewajiban memberikan informasi yang mendidik. Terdapat hal yang harus diperhatikan oleh TVRI kedepan dalam produksi ILM yaitu menentukan skala prioritas isu yang akan diangkat menjadi tema ILM. Sudah saatnya TVRI Bali memprioritaskan produksi ILM yang berkaitan dengan kewaspadaan bencana alam, kesehatan masyarakat, keselamatan umum dan kepentingan umum lainnya. Upaya mengangkat isu-isu tersebut juga akan selaras dengan konsep TVRI sebagai televisi publik yang mengutamakan kepentingan publik.

Wakil Ketua Komisi Penyiaran Indonesia Daerah (KPID) Bali I Gusti Ngurah Murthana, ST (wawancara 6 Mei 2019) mengakui jika selama 2017-Februari 2019 KPI Bali belum pernah melakukan evalusi terhadap pemenuhan kewajiban penayangan ILM oleh lembaga penyiaran. Evalusi tersebut belum dapat dilakukan karena adanya kerusakan alat pemantaua dan KPID Bali selama ini lebih fokus pada evaluasi program siaran. KPID Bali juga hanya sebatas mengingatkan lembaga penyiaran untuk menayangkan ILM dan itu hanya dilakukan saat kegiatan evaluasi dengar pendapat (EDP) pada saat lembaga penyiaran melakukan perpanjangan ijin. Selain itu, KPID Bali belum pernah mengeluarkan 
surat edaran guna mengingatkan lembaga penyiaran untuk memproduksi dan melaksanakan kewajiban menayangkan ILM dengan alasan lembaga penyiaran sudah mengetahui kewajiban memproduksi dan kewajiban menayangkan ILM. KPID Bali juga selama ini belum pernah melakukan koordinasi dengan BPBD Bali dalam upaya membantu penyebarluasan informasi mitigasi bencana dalam bentuk ILM melalui ILM. Hasil wawancara ini menunjukkan lemahnya penegakan hukum yang dilakukan KPID Bali terhadap lembaga penyiaran. Kenyataanya selama ini lembaga penyiaran cenderung tidak menjalankan kewajibannya karena lemahnya pengawasan dan evaluasi dari KPI, baik KPI pusat maupun KPI daerah.

Dampak dari tidak adanya evaluasi terhadap pemenuhan kewajiban oleh KPID Bali maka tidak ada pemberlakuan sanksi terhadap pelanggaran yang diperbuat oleh lembaga penyiaran. Pasal 83 SPS menyatakan bahwa lembaga penyiaran swasta yang tidak menyediakan waktu siaran untuk program siaran iklan layanan masyarakat paling sedikit 10 persen dari seluruh waktu siaran iklan niaga perhari, setelah mendapatkan teguran tertulis sebanyak 2 kali dikenakan sanksi administratif berupa denda administratif yang untuk jasa penyiaran radio paling banyak Rp. 100 juta. Sedangkan untuk jasa penyiaran televisi paling banyak Rp. 1 miliar. Apabila lembaga penyiaran, baik radio maupun televisi tidak melaksanakan denda administratif maka sanksi dapat ditingkatkan menjadi pembekuan kegiatan siaran sampai dipenuhinya kewajiban membayar denda administratif.

Hasil wawancara dengan Kepala Pelaksana Badan Penanggulangan Bencana Daerah (BPBD) Bali I Made Rentin (wawancara 5 Mei 2019) didapatkan bahwa selama ini BPBD belum pernah melakukan penyebarluasan informasi mitigasi bencana dalam bentuk ILM di lembaga penyiaran. Alasan pertama karena tidak ada anggaran untuk mendanai produksi dan penyiaran ILM. Alasan kedua karena tidak adanya SDM yang memadai untuk menyiapkan materi ILM dan ketiga karena kurang koordinasi dengan lembaga penyiaran dan Komisi Penyiaran Indonesia Daerah (KPID) Bali. Artinya peluang yang ada selama ini untuk melakukan penyebarluasan informasi mitigasi bencana dalam bentuk ILM melalui lembaga penyiaran khususnya TVRI belum dimanfaatkan secara optimal, dimana peluang belum dimanfaatkan secara optimal karena keterbatasan informasi dan koordinasi dengan KPID Bali dan lembaga penyiaran. Menurut Olivia dan Jane (2017), peran media dalam aktivitas pengurangan risiko dan manajemen bencana dapat membuat upaya pengurangan resiko dan manajemen bencana menjadi berfungsi lebih efektif. Kurangnya peran media hanya akan menyebabkan masyarakat kurang mendapatkan informasi terkait mitigasi bencana. Apalagi setiap informasi yang disampaikan media selalu dianggap oleh masyarakat sebagai sebuah kebenaran.

Implikasi dari temuan dari hasil penelitian yaitu perlu dibuat rencana strategis dalam upaya penyebarluasan informasi mitigasi bencana melalui lembaga penyiaran. Rencana strategis tersebut salah satunya adalah adanya koordinasi antara TVRI Bali ataupun lembaga penyiaran lainnya dengan BPBD dalam menyusun rencana penyebarluasan informasi bencana melalui ILM. Koordinasi nantinya dapat ditindaklanjuti dengan adanya MOU sehingga penyebarluasan mitigasi bencana dapat dilakukan secara terkoordinasi, terencana dan berkelanjutan. Penyebarluasan informasi mitigasi bencana kedepan juga tidak hanya dilakukan melalui ILM tetapi juga dalam bentuk pemberitaan, dialog ataupun dalam bentuk kegiatan non-air lainnya. Kebijakan perlu dibuat untuk memastikan bahwa jumlah ILM yang disiarkan cukup dan disiarkan pada waktu yang 
efektif. Perlu juga dibuat tentang perencanaan alokasi dana dan strategi untuk mengetahui efektivitas dari ILM yang disiarkan (Forbis et al., 2009). Selain itu, perlu strategi pengajaran dan pembelajaran yang efektif serta efisien untuk meningkatkan efektivitas kesiapsiagaan dan kegiatan pendidikan pengurangan bencana di semua tingkat masyarakat (Aghaei et al., 2018). Kedepan seluruh lembaga penyiaran televisi dengan format siaran apapun juga, wajib tanggap dalam program penyiaran bencana. Langkah ini akan menjadi bagian kontribusi penting dari dunia penyiaran terhadap nilai-nilai kemanusiaan (KPI, 2018).

Berdasarkan hasil penelitian maka dapat dibuatkan beberapa skema penyebarluasan informasi mitigasi bencana melalui lembaga penyiaran radio ataupun televisi. Pertama melalui skema lomba ILM mitigasi bencana dengan melibatkan Badan Penanggulangan Bencana Daerah (BPBD) Bali, Komisi Penyiaran Indonesia (KPI), Pemerintah Daerah dan Lembaga Penyiaran. Tantanganya perlu ada kepanitiaan dan keuntunganya kreasi ILM akan beragam, karena masing-masing lembaga penyiaran punya kreasi tersendiri. Kedua, Skema produksi yaitu Pemerintah daerah dalam hal ini BPBD Bali memproduksi ILM kemudian meminta bantuan kepada KPID Bali untuk disebarkan ke lembaga penyiaran agar disiarkan secara gratis. Skema kedua ini dapat dilakukan jika pihak pemerintah daerah tidak memiliki dana untuk biaya penyiaran. Tantanganya BPBD Bali harus memiliki tim produksi dan biaya produksi, tetapi keuntunganya ILM dapat diputar di berbagai lembaga penyiaran. Ketiga, Skema kerjasama produksi yaitu pihak BPBD Bali menyiapkan tema dan biaya produksi, sedangkan lembaga penyiaran yang memproduksi dan menyiarkan. Tantanganya harus ada dana yang dialokasikan pada lembaga penyiaran dan kelemahannya hanya akan diputar pada satu lembaga penyiaran yaitu lembaga penyiaran yang diajak melakukan kerjasama produksi. Kempat, skema kesadaran dan tanggungjawab. Skema ini hanya dapat diterapkan apabila lembaga penyiaran memiliki kesadaran akan aturan penyiaran ILM dan tanggungjawab untuk mematuhi aturan penyiaran. Dimana dalam skema kesadaran dan tanggungjawab BPBD Bali cukup hanya memberikan tema atau poin penting yang hendak disosialisasikan, kemudian lembaga penyiaran memproduksi dan menyiarkan tanpa meminta biaya sebagai bentuk tanggungjawab sosial terhadap pemanfaatan frekuensi milik publik.

\section{KESIMPULAN}

Berdasarkan data dan analisis maka dapat disimpulkan bahwa Tingkat pemenuhan penyebaran informasi mitigasi bencana oleh lembaga penyiaran TVRI Bali dalam bentuk ILM sangat rendah atau dapat dikatan belum melakukan pemenuhan, karena tidak ada ILM terkait mitigasi bencana. TVRI Bali memiliki kewajiban untuk memenuhi penyebaran informasi mitigasi bencana dengan memproduksi dan menyiarkan sesuai dengan ketentuan Undang-Undang Penyiaran, Pedoman Prilaku Penyiaran (P3) dan Standar Program Siaran (SPS).

TVRI Bali belum menempatkan isu mitigasi bencana sebagai isu penting untuk disampaikan kepada masyarakat dalam bentuk ILM. Produksi dan penyairan ILM oleh TVRI Bali masih berdasarkan trend isu yang muncul di masyarakat dan belum berdasarkan prioritas kepentingan publik.

Belum adanya koordinasi antara BPBD Bali dan TVRI Bali menyebabkan penyampaian informasi mitigasi bencana melalui ILM belum dapat dilakukan secara 
optimal. Kedepan TVRI Bali dan BPBD Bali perlu segera membuat kesepakatan kerjasama agar dapat memenuhi kebutuhan masyarakat akan ketersediaan informasi mitigasi bencana, sehingga masyarakat dapat berpartisipasi aktif dalam upaya mitigasi bencana.

\section{UCAPAN TERIMA KASIH}

Ucapan terima kasih penulis sampaikan kepada Kespsta TVRI Bali yang telah memberikan ijin untuk melakukan penelitian. Penulis sampaikan ucapan terima kasih juga kepada Kepala Pengembangan Program dan Pengembangan Usaha TVRI Denpasar, Drs. Juremi Wijaya yang telah membantu penulis dalam memberikan informasi terkait kebijakan-kebijakan yang berlaku di TVRI Bali. Ucapan terima kasih juga penulis sampaikan kepada Kasi Pengembangan Usaha, TVRI Bali, Sunar Wardoyon yang telah banyak membantu dalam mengumpulkan data rundown acara dan mengumpulkan videovideo ILM yang penulis perlukan untuk mempertajam analisis dalam penelitian. Penulis juga tidak lupa menyampaikan ucapan terima kasih kepada Kepala Pelaksana Badan Penanggulangan Bencana Daerah (BPBD) Bali I Made Rentin yang telah banyak membantu dalam mengumpulkan literatur terkait data-data kebencanaan di Bali.

\section{REFERENSI}

Aghaei, N., Seyedin, H., and Sanaeinasab, H. 2018. Strategies for disaster risk reduction education: A systematic review. Journal Education and Health Promotion, 7 : 98.

Ambarita, F.P. 2018. Penanggulangan Tindak Pidana Terorisme. Binamulia Hukum, 7 (2) : 141-156.

Ardiyasa, N.S., dan Suadnyana, 2017. Mitigasi Teologis Bencana Alam Dalam Naskah Lontar Roga Sanghara Bhumi. Genta Hredaya, 1 (1) : 60-69.

Asteria, D. 2016. Optimalisasi Komunikasi Bencana di Media Massa Sebagai Pendukung Manajemen Bencana. Jurnal Komunikasi, 01 : 1-11.

Ayu, N.L., Mayangsari, I.D., dan Aprianti, A. 2016. Analisis Manajemen Strategis Program Berita Indonesia Malam Lembaga Penyiaran Publik TVRI. e-Proceeding of Management : 3 (1) : 818-824.

Beritabali. 2018. Komisioner KPI : Lembaga Penyiaran Wajib Sosialisasikan Pemilu 2019 Melalui ILM (Seri online, 01 November 2018). Tersedia https://www.beritabali.com/ read/2018/ 11/01/201810310014/Komisioner-KPI-Lembaga-Penyiaran-Wajib-Sosialisasikan-Pemilu-2019-Melalui-ILM.html (diakses pada 5 Mei 2019)

Cooper, C.P., Gelb, C.A., and Chu, J. 2015. Life Cycle of Television Public Service Announcements Disseminated Through Donated Airtime. Preventive Medicine Reports, 2 (2015) 202-205.

Dennis, F.N., Yaulie, D.Y.R., dan Stanley, D.S.K. 2016. Geographical Information System (GIS) untuk Mitigasi Bencana Alam Banjir di Kota Manado. E-Journal Teknik Elektro dan Komputer, 5 (2) : 14-20.

Faturahman, B.M. 2018. Konseptualisasi Mitigasi Bencana Melalui Perspektif Kebijakan Publik. Jurnal Ilmu Administrasi Publik, 3 (2) : 122-134. 
Forbis, F.A., Nadorff, P.G., and Snyder, L.B. 2009. Analysis of Public Service Announcements on National Television, 2001-2006. Social Marketing Quarterly, $15(1): 49-69$.

Gurtner, Y. (2016). Returning to paradise: Investigating issues of tourism crisis and disaster recovery on the island of Bali. Journal of Hospitality and Tourism Management, 28, 11-19. doi:10.1016/j.jhtm.2016.04.007

Hastuti S. 2013. Efektivitas Iklan Layanan Masyarakat di Televisi. Jurnal Ilmu Komunikasi. 2 (2) : 67-72.

Inan, D. I., Beydoun, G., and Pradhan, B. 2018. Developing a decision support system for Disaster Management: Case study of an Indonesia volcano eruption. International Journal of Disaster Risk Reduction, 31, 711-721. doi:10.1016/j.ijdrr.2018.07.020

Keizer, D.P. 2010. Citra Perusahaan Dalam Tayangan Acara Televisi Lokal. Humaniora, 1 (2) : 577-585.

KPI. 2008. Undang-Undang Republik Indonesia Nomor 32 Tahun 2002 Tentang Penyiaran. Komisi Penyiaran Indonesia, Jakarta.

KPI, 2018. Lembaga Penyiaran Harus Berkontribusi Dalam Mata Rantai Penanggulangan Bencana (Seri online, 05 September 2018). Tersedia : http://www.kpi.go.id/index.php/id/umum/38-dalam-negeri/ 34664-lembagapenyiaran-harus-berkontribusi-dalam-mata-rantai-penanggulangan-bencana (diakses pada 5 Mei 2019)

Kunreuther, H. 2006. Disaster Mitigation and Insurance: Learning from Katrina. The ANNALS of the American Academy of Political and Social Science, 604(1), 208227. doi:10.1177/0002716205285685.

Tersedia https://journals.sagepub.com/doi/abs/10. $1177 / 000$ 2716205285685? journalCode=anna

McAbee, T.A., and Cafferty, T.P. 1982. Television Public Service Announcements as Outreach for Potential Clients. American Journal of Community Psychology, 10 (6) : 723-738.

Mustika, D.N., dan Zakaria. 2014. Pengaruh Iklan Layanan Masyarakat Hiv/Aids Media Televisi Versi “ Ko Tra Kosong Kalo Ko Jaga Diri ” Terhadap Sikap Mahasiswa Fakultas Ekonomi Universitas Yapis Papua. Jurnal Manajemen dan Akuntansi, 1 (2), 259-266.

Mustika, R. 2012. Budaya Penyiaran Televisi di Indonesia Broadcast Television Culture In Indonesia. Masyarakat Telematika dan Informasi, 3 (1) : 51-56.

Nakamura, K., and Bourdeau, F.A. 2006. A Critical Analysis of Public Service Broadcasting in a Digital Environment - Its Changing Role in Japan from the International Comparative Viewpoint (August 15, 2006). Tersedia di https://ssrn.com/abstract=2118974

Neonisa, D. 2011. Peran Iklan Layanan Masyarakat Dalam Sosialisasi Program Busway Oleh Pemprov DKI: Proses Sosialisasi Program Busway. Humaniora, 2 (2) : 14461466.

Nisa, N.K. 2015. Strategi Kreatif Iklan Layanan Masyarakat (Ilm) Dalam Pemasaran Sosial. Jurnal Interaksi, 4 (2) : 158 - 164.

Olivia, K., and Jane, S. 2017. Mainstreaming Media into Disaster Risk Reduction and Management, South Africa. Disaster Advances, 10 (7) : 1-11.

Priyowidodo, G., dan Luik, J.E. 2013. Literasi Mitigasi Bencana Tsunami Untuk Masyarakat Pesisir di Kabupaten Pacitan Jawa Timur. Jurnal Ekotrans, 13 (1) : 4761. 
Rudianto. 2015. Komunikasi dalam Penanggulangan Bencana. Jurnal Simbolika, 1 (1) : 51 61.

Suhardjo, D. 2011. Arti Penting Pendidikan Mitigasi Bencana Dalam Mengurangi Resiko Bencana. Cakrawala Pendidikan, XXX, (2) : 174-188.

Wardyaningrum, D. 2018. Kepercayaan Masyarakat Terhadap Informasi Tradisional dan Modern Pada Peristiwa Bencana Alam. Jurnal ASPIKOM, 3 (4) : 609-622.

Wulandari, N.A.D. 2016. Lembaga Penyiaran Publik Indonesia Dalam Persimpangan Idealisme Vs Ekonomi Politik Media. Jurnal Interaksi, 5 (1) : 78 - 89 